\title{
Distribution and Biomass of Halophila ovalis (R. Brown) Hook. f. at Pulau Gazumbo, Penang, Straits of Malacca
}

\section{AUTHOR(S):}

Razalli, Norhanis M.; Peng, Teh Chiew; Yusof, Mohd. Shukri Mohd.; Mohamed, Juliana; Hwai, Tan Shau; Yasin, Zulfigar; Abdullah, Anisah Lee

\section{CITATION:}

Razalli, Norhanis M....[et al]. Distribution and Biomass of Halophila ovalis (R. Brown) Hook. f. at Pulau Gazumbo, Penang, Straits of Malacca. Publications of the Seto Marine Biological Laboratory 2011, 41: 71-76

\section{ISSUE DATE:}

2011

URL:

http://hdl.handle.net/2433/159481

RIGHT: 


\title{
Distribution and Biomass of Halophila ovalis (R. Brown) Hook.f. at Pulau Gazumbo, Penang, Straits of Malacca
}

\author{
Norhanis M. Razalli' , *, Teh Chiew Peng ${ }^{1}$, Mohd. Shukri Mohd. Yusof ${ }^{1}$, Juliana Mohamed ${ }^{1}$, \\ Tan Shau Hwai ${ }^{1}$, Zulfigar Yasin ${ }^{1}$ and Anisah Lee Abdullah ${ }^{2}$
}

\begin{abstract}
${ }^{1}$ Marine Science Lab, School of Biological Sciences, Universiti Sains Malaysia, 11800 Minden, Penang, Malaysia.
${ }^{2}$ Geography Section, School of Humanities, Universiti Sains Malaysia, 11800 Minden, Penang, Malaysia.

E-mail addresses: norhanis86@gmail.com (M. R. Norhanis),cherrie_tcp@yahoo.com (C.P. Teh), bcb3110@yahoo.com (M. Y. M. Shukri), banosbest_85@yahoo.com (M. Juliana), aileen@usm.my (S. H. Tan), zulfigarusm@yahoo.com (Y.Zulfigar), anisah@usm.my (L.A. Anisah)

${ }^{*}$ Corresponding author: Tel: +6046533500 Fax: +6046533500
\end{abstract}

\begin{abstract}
Pulau Gazumbo is a small man-made island $\left(14.25 \mathrm{~km}^{2}\right)$ located in the Straits of Malacca, however it has an extensive seagrass bed that mainly consist of Halophila ovalis surrounding the island and extend to the subtidal area. This paper aims to study the distribution and biomass of the dominant seagrass in the island after recolonization in 23-26 years. Three $50 \mathrm{~m}$ transects parallel to the shore, i.e. nearshore, middle and offshore, were established at the flat intertidal area at the northeastern part of the island. For each transect, twelve $50 \times 50 \mathrm{~cm}$ quadrates and $0.0035 \mathrm{~m}^{2}$ core were observed and collected for seagrass distribution and biomass data. $H$. ovalis were widely distributed at the offshore transect $\left(1.5 \mathrm{~km}^{2}\right)$ where the mudflat patches can be found followed by the seagrass at the nearshore transect $\left(1.2 \mathrm{~km}^{2}\right)$. More patchy and limited distribution of $H$. ovalis were observed at the middle transect $\left(0.6 \mathrm{~km}^{2}\right)$. Leaf biomass of $H$. ovalis was $44-47 \%$ of the total biomass and the highest below-ground biomass occurred at the offshore transect. Although the main threat to the seagrass ecosystem in this island is the construction work and reclamation of the coastline nearby, $H$ ovalis still can survive on the island.
\end{abstract}

Key words: Seagrass, distribution, biomass, intertidal

\section{Introduction}

Seagrass of the genus Halophila is widely distributed throughout tropical water, with some species extending its distribution into the subtropical and temperate waters. Halophila ovalis (R. Brown) Hook. $f$., which is the most common seagrass species that can be found in the tropical waters (Short et al., 2007), has been found in Pulau Gazumbo at the Strait of Malacca. It is a man-made island, with a coverage area of about $14.25 \mathrm{~km}^{2}$, which formed due to sand built-ups during the construction of the bridge from 1983 to 1986. It is surrounded by sandy beach, a stretch of mangrove and mudflat area on the western side, and an extensive seagrass bed on the eastern side of the island.

Much less is known about seagrasses occurrences along the Straits of Malacca due to the sedimentation problem, which causes the water to be turbid and murky on this side of the peninsula, in comparison to the eastern side that facing the South China Sea. The largest seagrass bed in the Peninsular Malaysia can be found in Merambong Shoal at the southern part of the peninsular. Den Hartog (1970) reported that $H$. ovalis is the first pioneer species to settle on newly available substrate. The nearest natural seagrass beds close to Pulau Gazumbo, that may act as donor of seagrass seedlings to the island, are Pulau Langkawi in Kedah, Malaysia and Had Chao Mai National Park in Trang, Thailand which is about $90 \mathrm{~km}$ and $230 \mathrm{~km}$, respectively, to the north; and in the south, Teluk Kemang in Negeri Sembilan, Malaysia, with the distance of approximately $380 \mathrm{~km}$.

Hence, this paper reported about natural recolonization of H. ovalis on a man made island and the aims of this paper is to describe the distribution and biomass of the dominant seagrass in the islet, 
Halophila ovalis, which occurs in an extensive monospecific bed for future potential refuge for various kinds of marine organisms.

\section{Materials and Methods}

The study site, Pulau Gazumbo, $\left(5^{\circ} 21^{\prime} \mathrm{N}, 100^{\circ} 19^{\prime} \mathrm{E}\right)$ is an island next to the Penang Bridge that links the mainland, Peninsular Malaysia, and the Penang Island at the Straits of Malacca (Fig. 1). It is a man-made island, with a coverage area of about $14.25 \mathrm{~km}^{2}$, which formed due to sand built-ups during the construction of the bridge from 1983 to 1986. It is surrounded by sandy beach, a stretch of mangrove and mudflat area on the western side, and an extensive seagrass bed on the eastern side of the island.

The distribution and biomass of Halophila ovalis, the dominant seagrass species in Pulau Gazumbo, were determined by sampling along three $50 \mathrm{~m}$ transects parallel to the shore i.e. nearshore, middle and offshore. Transects were established to determine changes in $\mathrm{H}$. ovalis distribution as affected by the intertidal zonation which is exposed during the low tide. For each transect, twelve predetermined $50 \times 50 \mathrm{~cm}$ quadrates and $0.0035 \mathrm{~m}^{2}$ core were observed for percentage cover $(0-100 \%$ scale) and collected for $H$. ovalis distribution and biomass data. Frequency of occurrence, average percent cover and density of $H$. ovalis in each quadrate in each transect were calculated using the following formulae:

Frequency of occurrence $=$ number of occupied quadrats $/$ total number of quadrats

Average percent cover $=$ sum of percentage cover $/$ total number of quadrats

Average of density $=$ sum of density / total number of quadrats

Seagrass density and biomass was estimated from twelve replicate core samples $(10 \mathrm{~cm}$ depth) taken outside each quadrate by selecting an area of the same seagrass species and cover as the
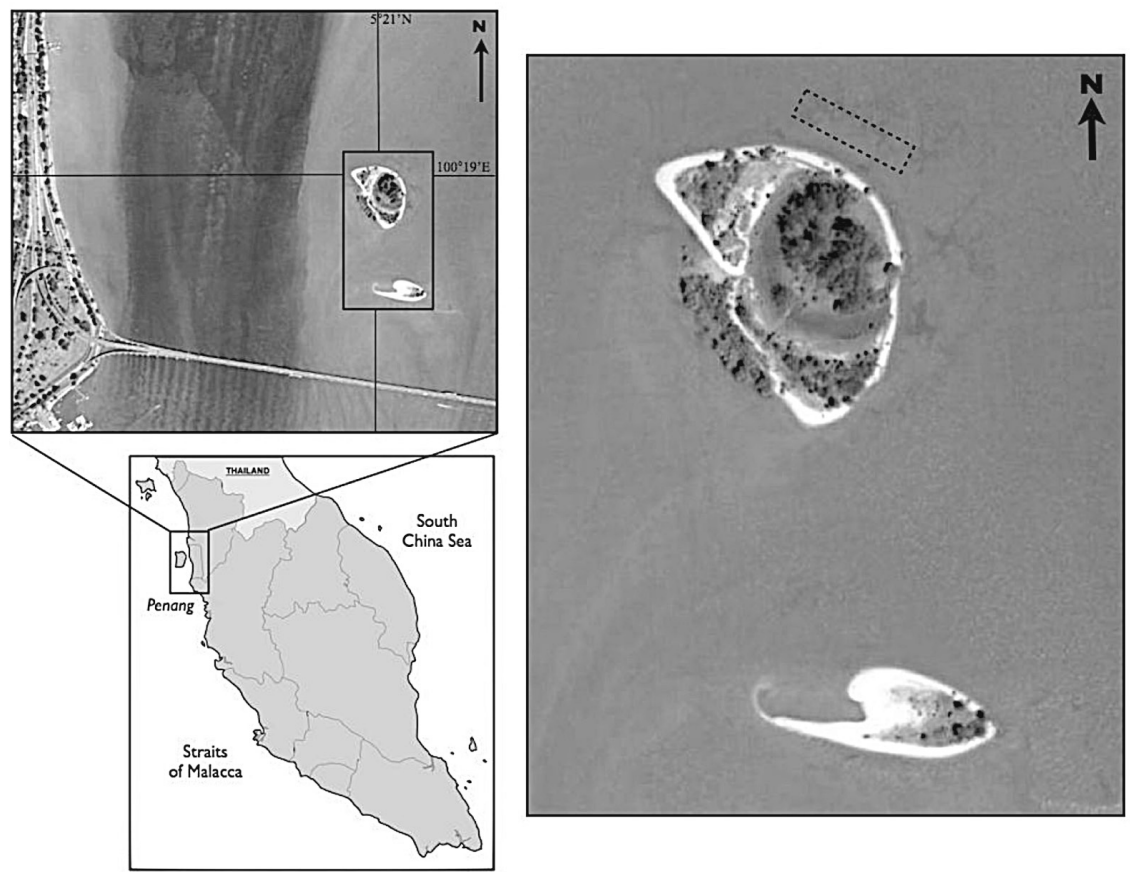

Fig. 1. Satellite image of Pulau Gazumbo with the location relative to the Straits of Malacca. Dotted box indicates seagrass sampling site on the island. 
quadrate. In each core, the number of $H$. ovalis shoots was recorded and later separated into leaves and root-plus-rhizome. Plant material was cleared of epiphytes by rinsing in a weak acid, washed and then dried in an oven at $60^{\circ} \mathrm{C}$ for 24 hours before being weigh for dry biomass data. Environmental data such as water temperature, salinity and surface sediment characteristics were also recorded during the sampling.

\section{Results}

Spot measurements of environmental factors made during the sampling gave a mean temperature of $29.2^{\circ} \mathrm{C}$ and salinity of $28 \mathrm{ppt}$. Observation on the surface sediment characteristic at all three nearshore-to-offshore transects reveal changes from sandy to muddy area, accordingly. Total average biomass data for H. ovalis at Pulau Gazumbo is shown in Table 1. Variation of H. ovalis biomass with the intertidal zonation is seen at Pulau Gazumbo with the highest total average biomass recorded at the offshore transect $\left(19.5 \pm 18.9 \mathrm{~g} \mathrm{DW} \mathrm{m}^{-2}\right)$, followed by nearshore transect $\left(10.1 \pm 14.6 \mathrm{~g} \mathrm{DW} \mathrm{m}^{-2}\right)$, and the least was recorded at the middle transect $\left(7.9 \pm 7.5 \mathrm{~g} \mathrm{DW} \mathrm{m}^{-2}\right)$.

Frequency of occurrence was calculated to show the occurrence of $H$. ovalis in the quadrates for each transect with the highest value is 1 , which means that $H$. ovalis occurs in all quadrate in the transect. Whereas, average percent cover was calculated to show the magnitude of its percent cover in each quadrate. Overall, H. ovalis was more predominant in the deeper area although the frequency is moderate with a value of 0.83 (Fig. 2), and this is clearly shown by the highest biomass and average percent cover per quadrate (53\%) at the offshore transect as shown in Table 1 and Fig. 3. This is followed by the nearshore transect, which recorded the average percent cover of $38 \%$ of $\mathrm{H}$. ovalis per

Table 1. Total average biomass of Halophila ovalis at Pulau Gazumbo.

\begin{tabular}{llll}
\hline Site & $\mathrm{N}$ & $\begin{array}{l}\text { Total average biomass } \\
\left(\mathrm{g} \mathrm{DW} \mathrm{m} \mathrm{m}^{-2} \mathrm{s.e} .\right)\end{array}$ & $\begin{array}{l}\text { Range } \\
\left(\mathrm{g} \mathrm{DW} \mathrm{m}^{-2}\right)\end{array}$ \\
\hline Nearshore & 12 & $10.1 \pm 14.6$ & $0.9-48.5$ \\
Middle & 12 & $7.9 \pm 7.5$ & $3-20.5$ \\
Offshore & 12 & $19.5 \pm 18.9$ & $3.4-61.9$ \\
\hline
\end{tabular}

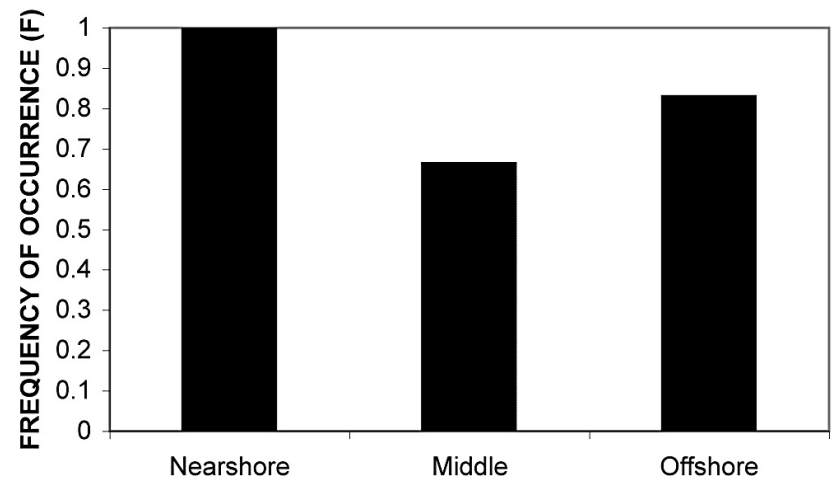

Fig. 2. Frequency of Halophila ovalis occurrence in each transect at Pulau Gazumbo. 


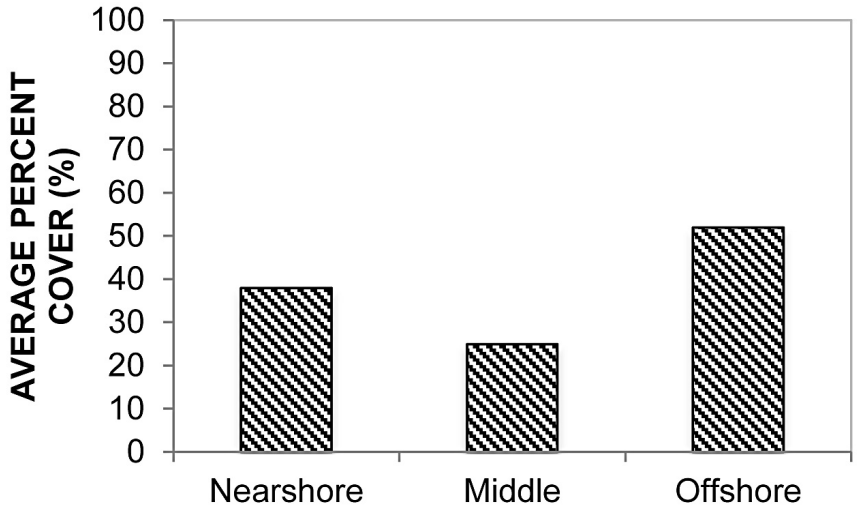

Fig. 3. Average percent cover of Halophila ovalis in each transect at Pulau Gazumbo.

quadrate. Despite that, the seagrass occurred in all quadrate in the transect $(\mathrm{F}=1)$. The least is the middle transect, which recorded $24 \%$ of $H$. ovalis per quadrate with the least occurrence of the seagrass in the transect $(\mathrm{F}=0.67)$.

At all transect, biomass of $H$. ovalis was about equally distributed between leaves (44-47\% of the total biomass) and, roots-plus-rhizomes, and highest biomass for each separated components occurred in the deeper site, which is the offshore transect followed by the nearshore transect and middle transect (Fig. 4). The density of $H$. ovalis in each transects reveals a similar pattern as other variables that have been measured (Fig. 5). The highest density was recorded at the offshore transect (9333 \pm 6087 shoots $\left.\mathrm{m}^{-2}\right)$ followed by the nearshore transect $\left(5857 \pm 4508\right.$ shoots $\left.\mathrm{m}^{-2}\right)$, and the least was recorded at the middle transect $\left(5571 \pm 6236\right.$ shoots $\left.\mathrm{m}^{-2}\right)$.

\section{Discussion and Conclusions}

The seagrass community at Pulau Gazumbo was dominated by Halophila ovalis, one of the most common seagrass species in the tropical region (Short et al., 2007). Interestingly, changes of the composition of seagrasses have been observed in this small islet especially after the tsunami hit in 2004 (Yasin and Tan, 2008). The population (biomass and diversity) of seagrass was reported to have increased after the tsunami, with an additional of two Halophila species, H. ovata and H. beccarii, in the community of seagrass in the island (Yasin and Tan, 2008). At the present time, very limited knowledge on the reproductive mechanisms of these species in order to better understand how they survive in stressful periods. Other seagrass species that also has been observed in the island are $H$. spinulosa (Tan et al., 2007) and Enhalus acoroides (Nadiah, 2008). All seagrass species in this island were observed in waters of less than $1 \mathrm{~m}$ in depth (Tan et al., 2007). It may be suggested that natural events such as tsunami may have brought the seedlings of seagrass (H. ovata, H. beccarii, $H$. spinulosa, and Enhalus acoroides) from the donor to the island itself, and the current may transport the seedlings during the rough sea condition.

Halophila ovalis exhibited little changes in percent cover, biomass and density at the first two transects from the shore, viz., the nearshore and middle transect. However, the percent cover, biomass and density increased at the offshore transect. These observations suggest that full development of seagrasses on Pulau Gazumbo may be limited by some environmental factors such as surface sediment characteristics. The sediment found at the offshore transect is mainly mud with fine sand. Because of the small rhizomes and, thus, low respiratory demand of this genus (Duarte, 1991), Halophila is commonly found to dominate the deeper edges of seagrass beds. Reproduction by seed may also 


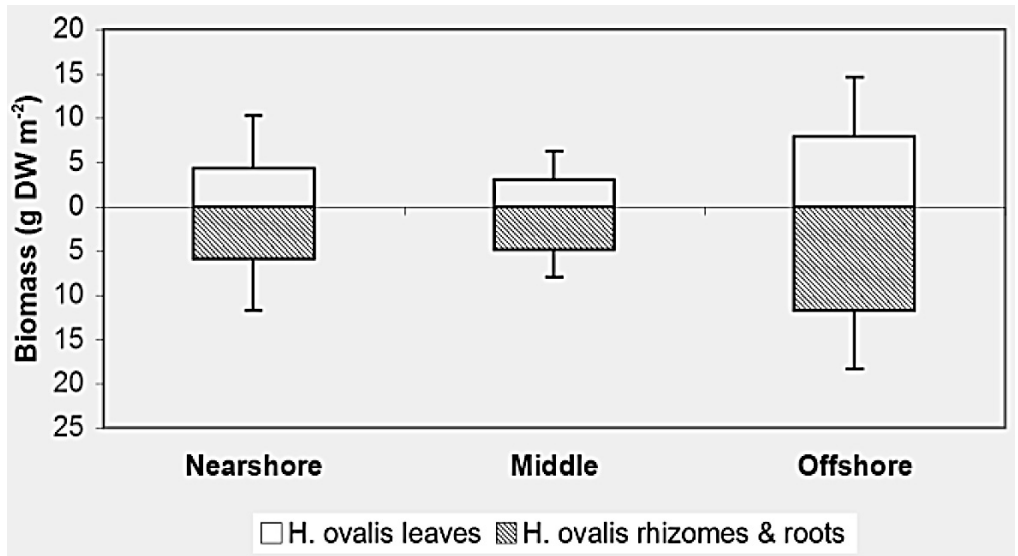

Fig. 4. Halophila ovalis biomass of each separated component in each transect at Pulau Gazumbo.

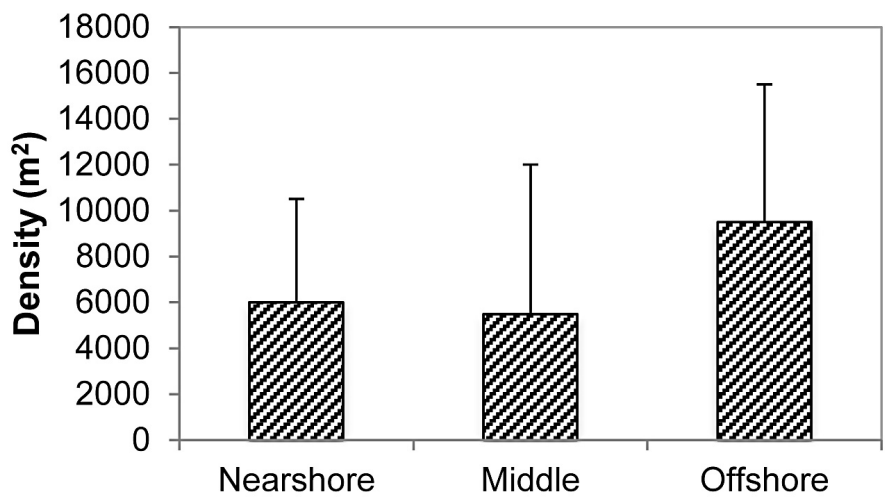

Fig. 5. Density of Halophila ovalis in each transect at Pulau Gazumbo.

increase the chances for Halophila to survive in deeper areas as temporary seed accumulates in the sediment (Kenworthy et al., 1989).

The major threat to the seagrass ecosystem in this island is the construction work and reclamation of the coastline nearby. An indication of stressful conditions in the vicinity area of Pulau Gazumbo is the relatively low abundance of larger-bodied seagrass such as Enhalus acoroides. E. acoroides can only be found in a small patch on the intertidal area. In a succession process, small and fast growing species are generally the colonizers whereas large and slow-growing species function as climax species (Marba and Duarte, 1998). The presence of E. acoroides in low density and H. ovalis being the dominant seagrass in the island since 1990s (Ahmad, 1995) shows that the progress of succession is taking place but favorable physical and biological conditions is persistently needed for the establishment of the climax species.

Although the distribution and biomass of the seagrass species in this island is relatively low compared to other seagrass ecosystem on the east coast of Peninsular Malaysia, Jupp et al. (1996) stated that these local pockets of well developed seagrass beds may be a resourceful haven among a wider regional distribution of smaller species and lower biomass of seagrass species, providing a valuable habitat for fish, crustaceans, herbivores and other important wildlife species. 


\section{Acknowledgements}

Support for this work was provided by the members of the Marine Science Lab USM and the undergraduates of BAT213 session 2009. Publication of this paper is financially supported in part by Natural Geography In Shore Areas (NaGISA) and Ministry of the Environment Japan (The Environment Research and Technology Development Fund S-9).

\section{References}

Ahmad, A. 1995. Kajian rumput laut di Beting Tengah, Pulau Pinang. BSc. Dissertation. School of Biological Sciences, Universiti Sains Malaysia.

Den Hartog. 1970. The seagrasses of the world. Verhandelingen der Koninklijke Nederlandse Akademie van Wetenschappen, Afd. Natuurkunde Tweede Reeks, dell 59, No. 1. North Holland Pub. Co. Amsterdam, $275 \mathrm{pp}$.

Duarte, C. M. 1991. Seagrass depth limits. Aquatic Botany, 40, 363-377.

Jupp, B. P., Durako, M. J., Kenworthy, W. J., Thayer, G. W. and Schillak, L. 1996. Distribution, abundance and species composition of seagrasses at several sites in Oman. Aquatic Botany, 53, 199-213.

Kenworthy, W. J., Currin, C. A., Fonseca, M. S. and Smith, G. 1989. Production, decomposition and heterotrophic utilization of the seagrass Halophila decipiens in a submarine canyon. Marine Ecology Progress Series, 51, 277-290.

Marba, N. and Duarte, C. M. 1998. Rhizome elongation and seagrass clonal growth. Marine Ecology Progress Series, 174, 269-280.

Nadiah, S. A. 2008. The seagrass communities of Pulau Gazumbo, Pulau Pinang. BSc. Dissertation. School of Biological Sciences, Universiti Sains Malaysia.

Short, F., Carruthers, T., Dennison, W. and Waycott, M. 2007. Global seagrass distribution and diversity: A bioregional model. Journal of Experimental Marine Biology and Ecology, 350, 3-20.

Tan, S. H., Nur-Najmi Basyeer, A. K. and Zulfigar, Y. 2007. Diversity of molluscs communities in the seagrass bed in Pulau Gazumbo, Penang, Malaysia. Marine Research in Indonesia, 32, 123-128.

Yasin, Z. and Tan, S. H. 2008. Effect of the tsunami on the marine systems of Malaysia. Paper presented at ASEAN Disaster Management: Enhancing Multilateral Approaches Across the Emergency Response Spectrum, Thailand, 25-26. 